\title{
Statistical analysis of State Fire Service intervention during chemical, radiation and biological hazards
}

\author{
Rafat Matuszkiewicz ${ }^{1, *}$ \\ ${ }^{1}$ The Main School of Fire Services, Faculty of Fire Safety Engineering, 52/54 Slowackiego St., \\ 01-629 Warsaw, Poland
}

\begin{abstract}
Contemporary civilisation is inherently accompanied by diverse disasters, industrial accidents, infectious diseases and increasingly frequent terrorist attacks, especially those arising from religious beliefs. Those phenomena will unfortunately keep happening as civilisation and modern industrial branches develop, even though increasingly advanced protection means are developed and deployed. The risk of occurrence of unexpected emergencies connected with the use of chemical, biological or radiation substances requires constant hazards monitoring by the State Fire Service (SFS). The paper presents a review of statistical data pertaining to the SFS interventions with respect to the above mentioned types of hazards. The executed quantitative and qualitative analysis of potential hazards allowed determination of the most frequent hazards occurring on the territory of the Republic of Poland. The binding legal regulations provide that the SFS is the leading service for counteracting those hazards, and therefore it is of importance to monitor hazardous factors and to foresee any change trends. The review takes into account statistical data for chemical and radiological hazards from the years 2013-2017 and biological hazards in the years 2015-2017.
\end{abstract}

\section{Classification of hazards}

Each year Fire and Rescue Units of the State Fire Service participate in a few hundred thousand rescue actions. Statistical data used in this paper were obtained from the decision support system of the National Headquarters of the State Fire Service and information from the National Coordination Centre for Rescuing and Population Protection of the National Headquarters of the SFS. In the analysed period there were a total of 2273516 SFS interventions, of which $31.2 \%$ (708 600) were fires, $62.4 \%$ (1 418 398) local hazards (defined as an incident other than a fire arising from civilizational development, human actions or natural forces, posing a hazard for health, property or the environment), while 6.4 $\%$ (146 518) were false alarms [1]. An important aspect of the analysis was recording the presence of hazardous substances during particular intervention types [2]. A classification was adopted that takes into account three main groups of hazards, and namely:

\footnotetext{
${ }^{*}$ Corresponding author: rmatuszkiewicz@sgsp.edu.pl
} 
- chemical hazards have been defined as release into the surroundings of hazardous substances, posing a hazard for the life, property or environment,

- radiation hazards have been defined as hazards related to radiation or radiation contamination,

- biological hazards have been defined as incidents of a terrorist nature with the use of a biological agent.

Based on this classification, data obtained from their recording system and information obtained directly from National Coordination Centre for Rescuing and Population Protection of the National Headquarters of the SFS, it was possible to determine the number of incidents for particular types of hazards [3-9]. In the analysed period there were a total of 35141 SFS interventions, in which chemical, radiological or biological hazards have been ascertained [10-14]. The biggest number of incidents was recorded for chemical hazards, $99.7 \%$ (35021). Biological hazards constituted $0.2 \%$ (77), while radiation hazards came up to $0.1 \%(43)$ [15-18].

\section{Chemical hazards}

Classification of a hazardous substance posing a chemical hazard is carried out pursuant to the assigned UN number [19-21]. This is a four digit identification code of the given substance, which is entered by the person in command to the form of incident report in the case of identification of a hazardous substance during rescue actions [22-25]. The list of UN numbers is contained in table A of the ADR Agreement and is issued by the United Nations Central Committee [26]. The present listing of UN numbers comprises 2914 items, which may be as a unique number for the specific substance, but also as a general number for entire groups of substances with similar properties, the so-called not otherwise specified (n.o.s.) [27]. Given such a high number of UN numbers recorded by persons in charge of a rescue action, for needs of devising statistical data adopted was a group of UN numbers, which has been recorded in minimum 12 incidents during a calendar year [28]. This information has been presented in figure 1 [29].

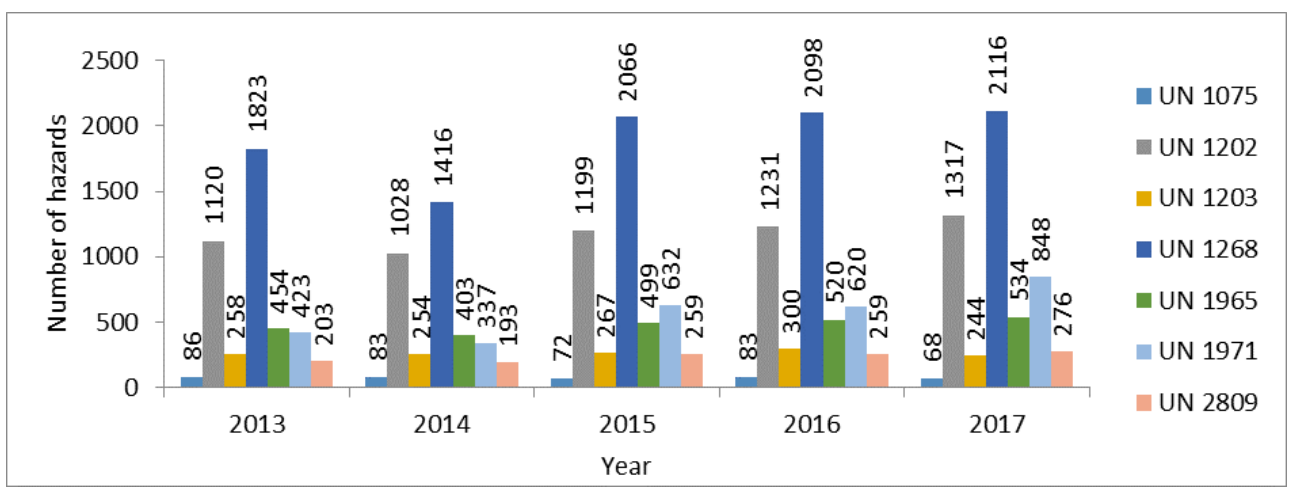

Fig. 1. Number of incidents for most frequent chemical substances.

According to the classification of hazardous substances, in the period of the last five years the most frequent were: liquefied petroleum gas (UN1075), gas oil or diesel fuel or heating oil, light (UN1202), gasoline or petrol or motor spirit (UN1203), petroleum distillates, n.o.s. or petroleum products, n.o.s. (UN1268), hydrocarbon gas mixtures, liquefied, n.o.s. (UN1965), compressed methane or compressed natural gas (UN1971) and mercury or mercury contained in manufactured articles (UN 2809) [30]. The above data allow the presumption that the most frequent UN numbers belong to class 3 and 2 of 
hazardous substances according to ADR regulations [31]. Given their physical and chemical properties, those substances comprise in the first place flammable substances [32]. As regards class 3 they additionally pose a hazard for the environment. As to mercury (UN2809), considered a class 6.1 hazardous substance, the nature of the hazard is quite different [33]. Mercury is highly toxic, which in the event of long-term exposition may lead to death. In the analysed period there were 35021 chemical hazards in Poland [34]. Their highest number was recorded in the Silesian province 23\% (8058), the Lesser Poland province $19.6 \%$ (6883) the Lower Silesian province 12.4\% (4358), the Masovian province 7.4\% (2596), the Greater Poland province 5.2\% (1810), the Lodzkie province 4.7\% (1634), the Podkarpackie province 4\% (1390), the Pomeranian province $3.9 \%(1375)$, the West Pomeranian 3,7\% (1305), the Warmian-Masurian province 3.6\% (1248), the Opole province $2.9 \%$ (1010), Kuyavian-Pomeranian and Lubelskie province 2.5\% (892). They were least frequent in the Lubuskie province $1.8 \%$ (613), the Swietokrzyskie province $1.67 \%$ (586) and the Podlaskie province 1.1\% (382).



Fig. 2. Number of incidents for most frequent chemical substances.

Figure 2 presents trends of changes related to the number of chemical hazards in Poland in the years 2013-2017. In the analysed period an increase took place of the number of incidents involving chemical hazards, i.e. 248 (2013-2014), 389 (2014-2015), 1085 (20152016), 1287 (2016-2017). Assuming that the hitherto trend would be maintained, it may be presumed that in 2018 ca. 11000 incidents involving chemical hazards may be expected [35-37].

\section{Radiation hazards}

The level of ionising radiation on the territory of Poland is constantly being monitored. This is done via a network of measurement stations comprised by the National System for Detection of Contamination and Alarm [38-39]. The objective of the system is the quickest possible detection of hazards that may arise from incorrect operation of diverse power plants situated in neighbouring countries. This system only enables monitoring of potential hazards arising due to release of radioisotopes to the atmosphere. It is not possible to point to incidents on a smaller scale [40-44]. The increasingly frequent use of radiation materials in industry, medicine or hydrology entails not only their transport to locations of their usage, but also to landfills designated especially for radiation materials after they have been used [45-49]. At present there are approximately 1800 registered enterprises in Poland that 
run their operation with the use of ionising radiation sources. The total number of closed radioactive sources in use by those enterprises amounts to ca. 20000 pcs. Radioactive sources most frequently used in medicine include cobalt-57 (57 Co), cobalt-60 (60 Co), caesium-137 (137C), radium (226 Ra), coal-14 (14 C), chromium-51 (51Cr), iodine-123 (123 I), technet-99 (99m Tc), tritium (3 H), and xenon-133 (133 Xe). In industry and in sciences most commonly used are: americium (241 Am), iridium-192 (192 Ir), nickel-63 (63 Ni), phosphorus-32 (32 P), plutonium (239 Pu), polonium-210 (210 Po), sodium-24 (24 $\mathrm{Na}$ ), thorium-229 (229 Th), uranium (235 U), and californium-252 (252 Cf). The ever growing need of using radioisotopes, in particular in medicine, has become a worldwide need, which results in a need of assuring appropriate preparation of rescue services to counteracting consequences of their uncontrolled release. Radiation hazards belong to rare occurrences on the territory of Poland. In the analysed period the number of radiation hazards in Poland comprised 43 incidents. The biggest number of hazards has been recorded in the Silesian province $32.6 \%$ (14), the Masovian province $13.9 \%$ (6), the Lower Silesian province $11.6 \%$ (5), Kuyavian-Pomeranian province and Warmian-Masurian province $9.3 \%$ (4), the Greater Poland province 7\% (3), Lodzkie and Lesser Poland province $4.7 \%$ (2), Podlaskie, Pomeranian and West Pomeranian province $2.3 \%$ (1). In the Swietokrzyskie, Podkarpackie, Opole, Lubuskie and Lubelskie province those hazards have not been recorded at all [50-56].

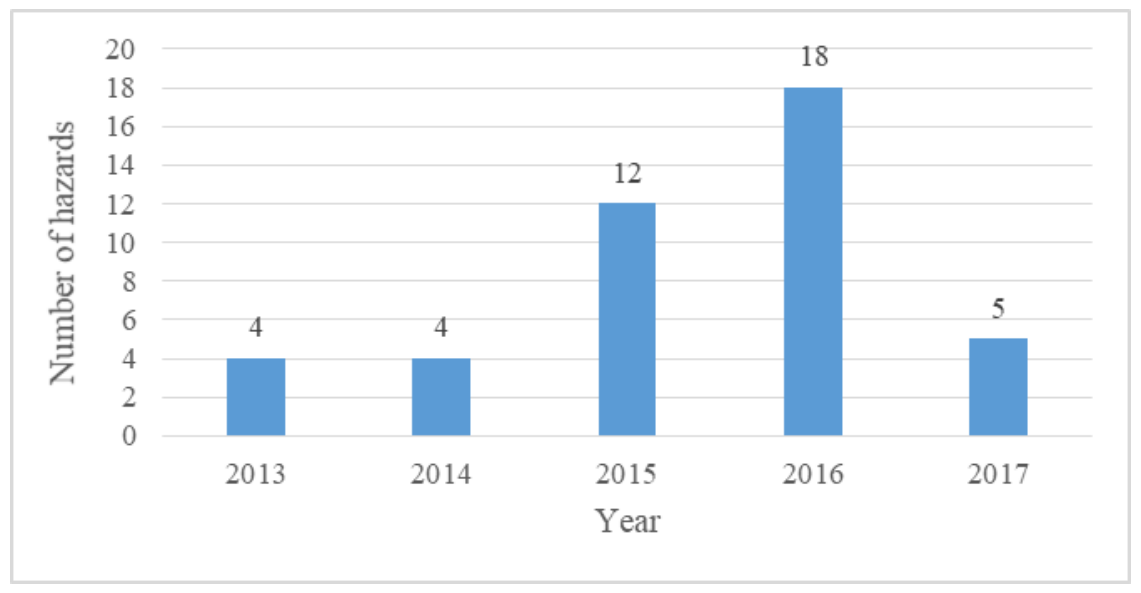

Fig. 3. Change trends of the number of radiation hazards in Poland.

Figure 3 presents change trends for the number of radiation hazards in Poland in the years 2013-2017. For this type of hazards, a significant increase was recorded in the years 2015-2016. However, in 2017 this number fell considerably to a level comparable to the one from before 2015 .

\section{Biological hazards}

The State Fire Service is involved in activities connected with hazards posed by particularly hazardous and highly infectious diseases following an evaluation and categorisation of the specific incident as an incident related to a hazard of biological factors belonging to two of four hazard groups i.e. group 3 or 4 (higher group number indicates a more severe hazard), and namely:

- group 3 of hazards - factors which may cause severe illness of people, which are hazardous for employees, and their spreading in the human population is highly 
probable. As a rule effective methods of their prevention or treatment exist - such as the anthrax bacteria;

- group 4 of hazards - factors which cause severe illness in people, which are hazardous for employees, and their spreading in the human population is highly probable. As a rule effective methods of their prevention or treatment are not in existence - such as the Ebola;

Tasks connected with counteracting the above mentioned hazards are being implemented by the SFS since 2015. Consequently the analysis of statistical data devised in this section pertained to the period of 2015-2017. As regards biological hazards, there is also a different method for recording incidents. Information concerning biological hazard is unfortunately not available in generally available statistics [57-58]. The recording of incidents is done directly via the National Coordination Centre for Rescuing and Population Protection of the SFS National Headquarters, which directly receives incident reports. Similarly as radiological hazards, biological hazards are not the most frequent occurrences on the territory of Poland. In the analysed period the number of biological hazards in Poland has been ascertained in 77 incidents [59-63]. The highest number of hazards has been determined in the Masovian province 52\% (38), the Lesser Poland province $11 \%(8)$, Silesian and West Pomeranian province 6.5\% (5), the Lubelskie province $5.2 \%$ (4), Pomeranian, Podkarpackie and Lodzkie province 3.9\% (3), Podlaskie and Greater Poland province $2.6 \%$ (2), Lower Silesian, Kuyavian-Pomeranian, Opole and Warmian-Masurian Voivodeship $1.3 \%$ (1). In the Swietokrzyskie and Lubuskie province such hazards have never been recorded. Based on the diagram from figure 4 a trend of changes has been determined of the number of biological incidents on the area of Poland [64].

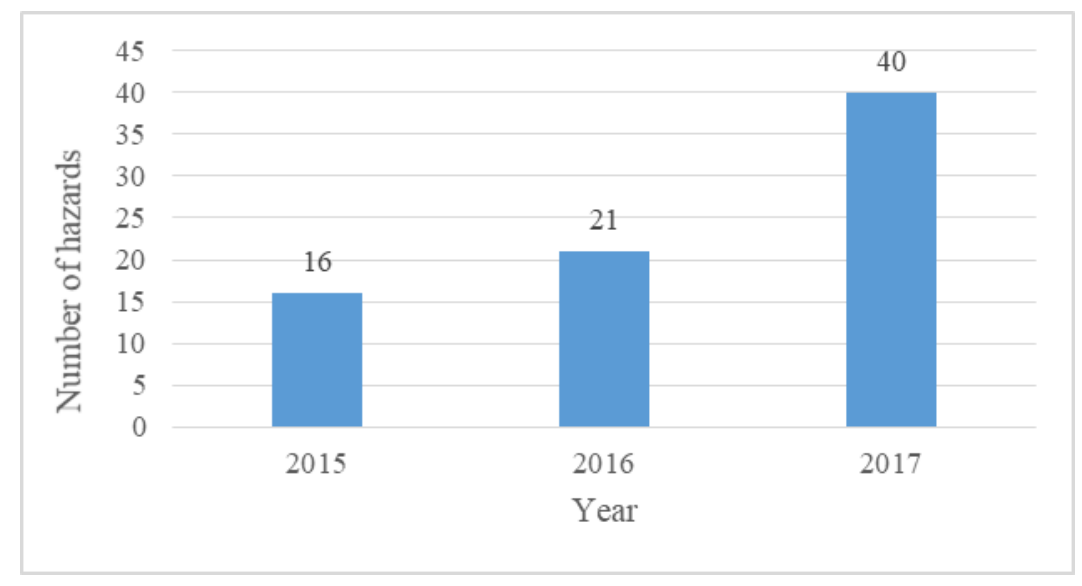

Fig. 4. Change trends of the number of biological hazards in Poland.

For the period of 2015-2016 a 30\% increase in the number of biological hazards was observed. On the other hand, for the period of 2016-2017 an almost 2-fold increase was recorded in the number of biological incidents. On the assumption that the presented trend would be maintained, in 2018 the number of recorded hazards of a biological nature may be expected at the level of approximately 80 .

\section{Conclusions}

In the analysed time period the number of all incidents involving Fire and Rescue Units of the State Fire Service came up to 2273 516, while the incidents during which detected were chemical, biological and radioactive hazards, has been detected in 35141 interventions. In 
Poland the biggest number of incidents was recorded for chemical hazards (35021). Biological hazards (77) and radiation hazards (43) have been recorded much less frequently. Provinces, in which the biggest number of recorded incidents for chemical and radiation hazards, included the Silesian province, and as regards biological ones - the Masovian province. On the other hand, in the Lubuskie and the Swietorzyskie province not a single biological or radiation hazard has been recorded. As regards chemical and biological hazards, in the analysed periods an increase was recorded in the number of hazards occurring. On the assumption that this trend would be maintained in 2018, their further growth may be expected. A quite different situation was observed for radiation hazards, as in their case the trend was completely different. Initially the occurrence of those hazards tended to grow, but in 2017 a significant decrease in their number was recorded. Projecting the number of hazards is not an easy task, as it varies depending on human factors and technical conditions arising from following safety rules and natural disasters.

\section{References}

1. W. Jarosz, Z. Salamonowicz, M. Majder-Lopatka, R. Matuszkiewicz, A. Dmochowska, Przem. Chem. 93 (2014)

2. M. Polka, Z. Salamonowicz, M. Wolinski, B. Kukfisz, Procedia Eng. 45 (2012)

3. A. Polanczyk, M. Podyma, L. Stefanczyk, W. Szubert, I. Zbicinski, J. Biomech. 48 (2015)

4. W. Eilenberg, S. Stojkovic, A. Piechota-Polanczyk, C. Kaun, S. Rauscher, M. Groger, M. Klinger, J. Wojta, C. Neumayer, I. Huk, S. Demyanets, Eur. J. Vasc. Endovasc. Surg. 51 (2016)

5. H. Zatorski, M. Salaga, M. Zielinska, A. Piechota-Polanczyk, K. Owczarek, R. Kordek, U. Lewandowska, C. Chen, J. Fichna, Naunyn. Schmiedebergs Arch. Pharmacol. 388 (2015)

6. A. Polanczyk, M. Strzelecki, T. Wozniak, W. Szubert, L. Stefanczyk, Found. Comp. Deci. Sci. 42, 13 (2017)

7. D. Dmochowski, A. Dmochowska, S. Biedugnis, ROS 17 (2015)

8. A. Piechota-Polanczyk, M. Zielinska, D. Piekielny, J. Fichna, Biomed. Pharmacother. 84 (2016)

9. A. Polanczyk, A. Piechota-Polanczyk, C. Domenig, J. Nanobachvili, I. Huk, C. Neumayer, Appl. Sci. 8, 14 (2018)

10. A. Polanczyk, M. Klinger, J. Nonobachvili, I. Huk, C. Neumayer, Appl. Sci. 8, 12 (2018)

11. L. Czyżewski, D. Beczek, K. Tomaszewski, D. Daniluk, E. Siemieniuk, Dis. Emerg. Med. 2, 4 (2017)

12. A. Polanczy, T. Wozniak, M. Strzelecki, W. Szubert, L. Stefanczyk, Signal Processing SPA 5 (2016)

13. A. Zieminska-Stolarska, A. Polanczyk, I. Zbicinski, J. Hydrol. Hydromech. 644, 8 (2015)

14. Z. Salamonowicz, W. Jarosz, BITP 3 (2012)

15. Z. Salamonowicz, M. Kotowski, M. Polka, W. Barnat, Przem. Chem. 93 (2014)

16. Z. Salamonowicz, M. Wolinski, M. Sobolewski, M. Polka, Przem. Chem. 93 (2014)

17. Z. Salamonowicz, M. Majder-Lopatka, BITP 30 (2013) 
18. A. Dmochowska, Wars. Univ. Tech. Pub. (2009)

19. A. Polanczyk, M. Podgorski, T. Wozniak, L. Stefanczyk, M Strzelecki, Medicina 54, 15 (2018)

20. Paul C. Darley, Fire App. Emerg. Equip. 23, 1 (2018)

21. Act of 24 August 1991 on fire protection (Journal of Laws of 1991 No. 81. item 351)

22. M. Wlodarczyk, A. Sobolewska-Wlodarczyk, A.I. Cygankiewicz, D. Jacenik, A. Piechota-Polanczyk, K. Stec-Michalska, W.M. Krajewska, J. Fichna, M. WisniewskaJarosinska, J. Gastrointestin. Liver Dis. 26 (2017)

23. M. Salaga, L.V. Blomster, A. Piechota-Polanczyk, M. Zielinska, D. Jacenik, A.I. Cygankiewicz, W.M. Krajewska, J.D. Mikkelsen, J. Fichna, J. Pharmacol. Exp. Ther. 356 (2016)

24. A. Piechota-Polanczyk, S. Demyanets, O. Nykonenko, I. Huk, M. Mittlboeck, C.M. Domenig, C. Neumayer, J. Wojta, J. Nanobachvili, M. Klinger, Eur. J. Vasc. Endovasc. Surg. 45 (2013)

25. A. Polanczyk, A. Piechota-Polanczyk, L. Stefanczyk, PLoS One 12 (2017)

26. A. Polanczyk, M. Podyma, L. Trebinski, J. Chrzastek, I. Zbicinski, L. Stefanczyk, PLoS One 11 (2016)

27. M. Salaga, U. Lewandowska, D. Sosnowska, P.K. Zakrzewski, A.I. Cygankiewicz, A. Piechota-Polanczyk, M. Sobczak, P. Mosinska, C. Chen, W.M. Krajewska, J. Fichna, Naunyn. Schmiedebergs Arch. Pharmacol. 387 (2014)

28. A. Piechota-Polanczyk, M. Wlodarczyk, A. Sobolewska-Wlodarczyk, M. Jonakowski, A. Pilarczyk, K. Stec-Michalska, M. Wisniewska-Jarosinska, J. Fichna, Dig. Dis. Sci. 62 (2017)

29. Act of 24 August 1991 on the State Fire Service (Journal of Laws of 1991 No. 88. item 400)

30. M. Majder-Lopatka and T. Wesierski, E3S Web of Conferences 46 (2018)

31. M. Majder-Lopatka, T. Wesierski, W. Wasik, BITP 42, 8 (2016)

32. A. Piechota-Polanczyk, A. Jozkowicz, Curr. Drug. Targets. 17 (2016)

33. A. Polanczyk, M. Podgorski, M. Polanczyk, N. Veshkina, I. Zbicinski, L. Stefanczyk, C. Neumayer, Interact. Cardiovasc. Thorac. Surg. (2018)

34. A. Polanczyk, P. Wawrzyniak, I. Zbicinski, Drying Technol. 31, 10 (2013)

35. P. Wawrzyniak, A. Polanczyk, I. Zbicinski, M. Jaskulski, M. Podyma, J. Rabaeva, Drying Technol. 30, 10 (2012)

36. Z. Salamonowicz, R. Makowski, E3S Web of Conferences 44 (2018)

37. P. Wawrzyniak, M. Podyma, I. Zbicinski, Z. Bartczak, A. Polanczyk, J. Rabaeva, Drying Technol. 30, 9 (2012)

38. A. Piechota, A. Goraca, J. Physiol. Pharmacol. 62 (2011)

39. Z. Salamonowicz, M. Kotowski, M. Polka, W. Barnat, Bull. Pol. Ac.: Tech. 63 (2015)

40. Ordinance of the Minister of Health of 22 April 2005 on harmful biological factors for health in the work environment and health protection of workers professionally exposed to these factors (Journal of Laws No. 81, item 716, as amended)

41. Ordinance of the Minister of Internal Affairs and Administration of 4 July $2017 \mathrm{y}$. on detailed rules for the organization of the national rescue and fire-extinguishing system (Journal of Laws of 2017, item 1319) 
42. Regulation for recording rescue actions in the Decision Support System of the State Fire Service, National Headquarters of SFS, Warsaw (2014)

43. Regulation of conduct SFS units in case of a suspected risk of disease particularly dangerous and highly infectious, National Headquarters of SFS, Warsaw (2015)

44. A. Polanczyk, Z. Salamonowicz, E3S Web of Conferences 44, 8 (2018)

45. D. Dmochowski, A. Dmochowska and S. Biedugnis, ROS 17 (2015)

46. A. Polanczyk, M. Podyma, L. Stefanczyk, I. Zbicinski, Chem. Eng. Process. 33, 9 (2012)

47. T. Wesierski, M. Majder-Lopatka, R. Matuszkiewicz, R. Porowski, Przem. Chem. 91, 3 (2012)

48. A. Piechota-Polanczyk, A. Goraca, Pharmacol. Rep. 64 (2012)

49. A. Piechota, A. Polanczyk, A. Goraca, Pharmacol. Rep. 63 (2011)

50. T. Wesierski, M. Majder-Lopatka, W. Wasik, Przem. Chem. 96, 5 (2017)

51. M. Majder-Lopatka, W. Rogula-Kozlowska, W. Wasik, E3S Web of Conferences 44 (2018)

52. A. Piechota, A. Polanczyk, A. Goraca, Pharmacol. Rep. 62 (2010)

53. A. Polanczyk, Z. Salamonowicz, E3S Web of Conferences 44, 8 (2018)

54. D. Dmochowski, A. Dmochowska and S. Biedugnis, ROS 17 (2015)

55. A. Polanczyk, M. Podyma, L. Stefanczyk, I. Zbicinski, Chem. Eng. Process. 33, 9 (2012)

56. T. Wesierski, M. Majder-Lopatka, R. Matuszkiewicz, R. Porowski, Przem. Chem. 91, 3 (2012)

57. A. Piechota-Polanczyk, A. Goraca, Pharmacol. Rep. 64 (2012)

58. A. Piechota, A. Polanczyk, A. Goraca, Pharmacol. Rep. 63 (2011)

59. A. Piechota-Polanczyk, A. Kopacz, D. Kloska, B. Zagrapan, C. Neumayer, A. Grochot-Przeczek, I. Huk, C. Brostjan, J. Dulak and A. Jozkowicz, Oxid. Med. Cell. Longev. 2018 (2018)

60. K. Kowalska, D. E. Habrowska-Gorczynska, C. Neumayer, M. Bolliger, C. Domenig, A. W. Piastowska-Ciesielska, I. Huk and A. Piechota-Polanczyk, Acta Biochim. Pol. 65, 1 (2018)

61. D. Kloska, A. Kopacz, A. Piechota-Polanczyk, W. Nowak, J. Dulak, A. Jozkowicz and A. Grochot-Przeczek, Vascul. Pharmacol. (2018) [in press]

62. A. Piechota, A. Polanczyk, A. Goraca, Pharmacol. Rep. 62 (2010)

63. T. Wesierski, M. Majder-Lopatka, W. Wasik, Przem. Chem. 96, 5 (2017)

64. M. Majder-Lopatka, W. Rogula-Kozlowska, W. Wasik, E3S Web of Conferences 44 (2018) 